\title{
TOTÁLNÍ MĚSTO
}

\author{
VÁCLAV CIMBÁL
}

\section{Moderní společnost - rozštěpení těla a mysli, př́rody a kultury}

\author{
„Př́roda není jen materie; je to i duch.“ \\ C. G. Jung
}

Německý básník Ludwig Tieck v pohádce Skř́ítci proti sobě staví dva světy. Úpravnou a plodnou kulturní zemědělskou krajinu, obdělávanou místními vesničany a divokou, na první pohled nevábnou a strach nahánějící divočinu obývanou cikány a jinými bídnými postavami. Druhý pohled, kterého jsou ale schopné pouze děti, básníci a jiní lidé obdaření fantazií, však v této divočině odkrývá svět obývaný elementárními bytostmi - skřítky a vílami. V závěru pohádky se vesničané neschopní vnímavějšího pohledu rozhodnou vyhnat cikány, divočinu vymýtit a přetvořit k obrazu svému. Poté i skř́ítci a víly opouštějí kraj, který však v tu chvíli ztrácí svou úrodnost a mění se ve vyprahlou krajinu [Tieck 1974: 87-106]. Kromě jiného lze z pohádky vyvodit, že dospělí, racionální, kulturou okleštění lidé nejsou schopni citového prožitku divočiny a nejsou tak schopni odhalit ani její krásu a tajemství. Druhým poznatkem pak je, že divočina je něco základnějšího a zásadnějš́ího, něco na čem stojí i náš kulturní svět, který s její smrtí také umírá. Posledním poznatkem pak je nutnost a potřeba rovnováhy mezi protikladnými silami v kultuře vyjádřená také dvojicí jin a jang, chaosem a řádem či nověji hmotou a antihmotou.

Člověk se jako biologický tvor vyvíjel v těsném kontaktu s př́rodou a tento kontakt tedy formoval jeho fyzické i psychické vlastnosti. Nelze idealisticky hovořit o jednoznačné lásce $\mathrm{k}$ př́rodě, spíše lze rozpoznat jak kořistnické a dobyvačné rysy tohoto vztahu, tak úctu a pokoru k neznámému a přesahujícímu světu př́rody. A snad ještě spíše lze o prýrodě mluvit jako o komplementární ke světu kultury, dávající jí smysl a život. Především však lze rozpoznat dlouhodobým evolučním vývojem vzniklý symbiotický vztah mezi př́rodou a kulturou. V oblastech, kde byl tento dlouhodobý vzájemný vývoj přeskočen, tam kde se stal člověk náhle novým prvkem ekosystému, jako např. v Severní Americe před zhruba 12000 lety, byl nově př́íchozí člověk pro nepřizpůsobenou přírodu větším nebezpečím (a naopak) než v místech svého původu [Ruddiman 2011: 90-93]. Od vzniku kultury tedy probíhal vývoj každého jednotlivce $\mathrm{v}$ dvojím prostředí, $\mathrm{v}$ prostředí př́rodním i v prostř̌edí kulturním. Vyvážený vztah k nim oběma zajištoval plnohodnotný rozvoj lidského jedince. Tedy plnohodnotný rozvoj rozumový, emoční, citový a tělesný. Tělesný rozvoj nemá pouze hodnotu estetickou či zdravotní, ale týká se př́mo geneze osobnosti, kterou nelze pojímat ve dvou liniích, jako genezi psychickou a genezi fyzickou. Celý svůj svět si osvojujeme v pohybu a př́mým fyzickým kontaktem s ním. Vztah ke 
světu našeho života je přímo spjat s naší fyzickou existencí. Po většinu své existence žilo lidstvo v podmínkách, které rovnoměrně umožňovaly kontakt s př́rodním i kulturním prostředím.

V 19. století však nastoupil člověk spolu s průmyslovou revolucí cestu urbanizace. Pojmu, užívám pro potřeby tohoto textu ve smyslu živelného růstu měst a jejich významu v době od průmyslové revoluce a pro šíření městského způsobu života na venkov. ${ }^{1}$ Tempo urbanizace se stále stupňuje. V roce 1900 žilo ve městech $13 \%$ obyvatel planety, v roce $195029 \%$ a roku 2008 se podíl městského obyvatelstva přehoupl přes $50 \%$ obyvatelstva, přičemž se uvádí, že v Evropě žije ve městech již dnes $80 \%$ obyvatelstva. Pro rok 2050 se pak v celosvětovém měřítku počítá se $70 \%$ podílem městského obyvatelstva [Mezřický 2011].

V současných vyspělých státech probíhala urbanizace pomaleji než v rozvojových zemích, po počátečním živelném období postupně vstoupila do další fáze, v níž již není jedinou a hlavní hybnou silou dalšího rozvoje měst migrace a růst počtu obyvatel, ale jiné faktory jako např. zvyšující se nároky na obytnou plochu. Naopak v rozvojových zemích probíhá urbanizace rychleji a stále je hnána především př́livem nových obyvatel. Počáteční fáze urbanizace je spojena s růstem chudoby a asociálních jevů. Ve vyspělých zemích se míru extrémní chudoby podařilo snížit, míra asociálních jevů poklesla méně, je však otázkou zda se se svými slumy a kriminalitou dokážou vyrovnat, alespoň v míře rozvinutých států, i dnes vznikající megalopole třetího světa. Přesun obyvatelstva do měst s sebou nese změnu způsobu obživy obyvatelstva. Nejprve od zemědělství k průmyslu a poté od průmyslu ke službám, administrativě, expertní práci a řízení procesư. Vzhledem k našemu tématu je však důležitější jak se změnil vztah k přírodnímu prostředí, ale také jak se změnil zpơsob osvojování okolního hmotného světa, který stojí v základech vztahu k př́rodě a divočině.

Růst měst a růst průmyslu byl podmíněn, vedle rozvíjejícího se kapitalistického systému a vedle touhy po zisku, osvícenskými idejemi, touhou osvobodit člověka $\mathrm{z}$ často kruté vlády prrírody, ulehčením mu v jeho životním údělu, usnadněním obživy, odstraněním těžké dřiny a bídy. Je nutné objektivně konstatovat, že řadu z těchto cílů se podařilo naplnit: kapitál utěšeně roste, $\mathrm{v}$ rozvinutých zemích se alespoň podařilo vymýtit krutou bídu, lidský život se prodlužuje, těžké dřiny na polích, v dolech, v těžkých provozech ubylo. Je však nutné stejně objektivně upozornit na cenu, za kterou k tomu došlo: kapitál je skutečným vládcem, kapitál je cennější než lidská práce, pohodlnější život je umožněn zpřetrháním vazeb s přírodou a s přirozeným světem, vytvořením bariéry mezi člověkem a přírodou, virtuální světy jsou reálnější než přirozený svět, pohodlnější práce je vykoupena umrtvením těla $v$ kancelářských provozech. A právě posledně jmenovaná cena zaplacená za pohodlí může být chápána jako symbol celého vzdalování se člověka přírodě. To proto, že vytvárí bariéru mezi tělem a myslí, jakoby popírala vše, s čím přišla fenomenologická filosofie v čele s Maurice Merleau-Pontym. Přehlížíme, že mysl se rozvíjí v tělesném kontaktu s prostředím a své obsahy čerpá především z něj.

Řečeno s filosofem Josefem Šmajsem, sociokulturní informace vzniká třetím čtením přirozeného prostředí, sociokulturní informace je pak, dle názoru Josefa Šmajse, zakó-

1 Ruku v ruce s připodobňováním vesnického života tomu městskému dochází také k urbanizaci venkovské krajiny: infrastruktura, průmyslová výstavba na zelené louce (např. Hyundai Nošovice). 
dována v jazyce [Šmajs 2011: 211]. Domnívám se však, že je nutné tuto myšlenku rozšírit a považovat za kód třetího čtení nejenom jazyk, ale i další systémy člověkem vytvořené a užívané. Především jde o vizuální umění, nebo lépe řečeno o vizuální vyjádření uměleckých, náboženských a mytologických obsahů. Jedná se tedy o vymezení blízké tomu, které podal Ernest Cassirer. Ten v souvislosti se vznikem symbolo̊ dokazuje jejich spjatost se základní situací člověka ve světě a se základními kategoriemi času a prostoru. Při tvorbě symbolických obsahů lze vystopovat dvě vztažné soustavy. První soustava je vázána na člověka, který je jejím středem a tím pádem i jakýmsi pomyslným středem světa. Geneze symbolů tedy postupuje od „Já“ k „Ne-Já“ a od konkrétních pojmů k obecným a abstraktním. Druhá soustava je vázána na přirozený prostor, odtud se pak např. odvozuje symbolický význam světových stran v náboženství a jejich promítnutí do sakrálních staveb a průběhu rituálů [Cassirer 1996], orientace podle světových stran se promítá do architektury od dob Vitruvia i v praktičtější rovině a jejím cílem je dosažení optimálního obytného prostředí staveb (světlo, teplo, vlhkost). Prostředí je vztažným rámcem i na nižších úrovních než jsou světové strany, stavby se orientují např. vzhledem k horám, vodním plochám atd. Vzájemný vztah obou soustav pak umožňuje nejenom praktickou orientaci, ale stojí také v základech lidského vztahu ke světu.

Sociokulturní informaci tedy tvoří více systémů, ne pouze jazyk a není jednovrstvá. Pro její adekvátní popis je nutné vedle pojmu symbolu postavit pojem znaku, v distinkci jakou provedla filosofie počínaje právě E. Cassirerem a dále filosofií fenomenologickou. $\mathrm{V}$ české literatuře distinkci znaku a symbolu asi nejuceleněji podal Ivan Mucha v knize Symboly v jednání. Pro tuto stat bude postačovat, uvedu-li, že symbol odkrývá mnohé další roviny světa, a vyžaduje interpretaci, nebot’ k jeho základním vlastnostem patří nejednoznačnost a enigmatičnost. Naopak znak se vždy vztahuje k téže rovině, je součástí sémantické struktury a práce s ním nevyžaduje interpretaci, ale pochopení [Mucha 2000]. Kulturu pak lze vymezit jako celek tvořený symboly, znaky, artefakty a jednáním. Zároveň je kultura závislá na starších přírodních strukturách a nevytváří tedy autonomní realitu. K těmto strukturám, člověku vnitřním i vnějším, se vztahuje symbolická kulturní vrstva, znakový systém slouží vnitřní organizaci kultury. Aby byla kultura životaschopná, musí se všechny zmíněné složky rozvíjet ve vzájemném souladu.

Maurice Merleau-Ponty se ve své filosofii snažil rehabilitovat smyslové vnímání našeho světa jako plnohodnotné a neukazující pouze zdání a přelud zakrývající skutečnou podstatu světa. Její poznání bylo v dobovém myšlení vyhrazeno pouze vědě. Merleau-Ponty vědu neodsuzuje, pouze jí chce vykázat či přesně vymezit její oblast zájmu a zároveň se snaží vyvrátit přesvědčení o tom, že věda popisuje a postihuje samu podstatu světa. Také ve vědě je, stejně jako v každodenním smyslovém poznání, poznávaný předmět ovlivněn poznávajícím, tedy vědeckou metodologií a použitými přístroji. Vědy vytváří pouze přibližné popisy světa, které s realitou korespondují, nejzřetelněji se tato skutečnost projevuje v kvantové mechanice, rozhodně však nejsou se zkoumanou podstatou totožné. Je tak vyvrácena představa předmětu spočívajícího $\mathrm{v}$ homogenním prostoru pozorovatelném $\mathrm{z}$ pevného bodu umožňujícím zcela objektivní poznání. ${ }^{2}$ Prostor, předmět a pozorovatel jsou ve vědě neoddělitelné. Stejně tak jsou však neoddělitelné i př̀i každodenním smyslovém vnímání. Absolutní nadřazenost vědy i nedostatečnost smyslového vnímání jsou tak překonány.

Viz Heisenbergův princip neurčitosti. 
Merleau-Ponty dokazuje, že si neoddělitelnosti předmětů, prostoru a pozorovatele všimli již moderní malíŕi. Jako př́klad předkládá Cézanna, který opustil klasickou techniku, kdy jsou od sebe odděleny kresby obrysů předmětů a následná barevná malba. Absencí ostrých kontur Cézanne poukazuje na plynulost přechodů přirozeného světa. Cézanne také opouští klasickou perspektivu, která znásilňuje realitu i pozorovatele. Obraz, který si ve vědomí vytváríme, není konstruován podle pravidel perspektivy. Reálně pozorujeme předměty $\mathrm{z}$ různých úhlů pohledu a nikoliv vztažené $\mathrm{k}$ úběžnému bodu. Je tak vytvářen prostor, slovy Jeana Paulhana, jejž lze „cítit srdcem“, prostor, v němž jsme sami zasazeni, prostor kolem nás, prostor s námi organicky spojený. M. Merleau-Ponty k tomu dodává, že náš vztah k prostoru „není vztahem čistého netělesného subjektu ke vzdálenému objektu, ale spíše vztahem obyvatele $\mathrm{k}$ jeho důvěrně známému prostředí“ [Merleau-Ponty 2008: 22]. Namísto homogenního prostoru „jenž se naráz předkládá netělesnému intelektu“ tak nastupuje „idea prostoru heterogenního, v němž mají přednostní postavení některé směry, které souvisejí s našimi tělesnými zvláštnostmi a naší situací bytostí vržených do světa“ [Merleau-Ponty 2008: 22]. Člověk není rozštěpitelný na tělo a ducha, ale je nedílnou jednotou, existující mezi ostatními věcmi, které díky tomu může poznávat.

Ve stejné organické jednotě, do které vstupují věci s prostorem a pozorovatelem, spočívají také jejich vlastnosti. Pozorujeme-li podle Merleau-Pontyho nějaký předmět, nevnímáme jeho vlastnosti oddělně a nespojujeme je až následně v jednotný obraz. Realita je taková, že jednotlivé kvality nejsou izolované, ale jsou propojeny s ostatními smysly. Tak barva ovoce může odkazovat na chut', tvar na vůni atd. ${ }^{3}$

Moderna spojila tři síly - průmyslovou revoluci, urbanizaci a sekularizaci. Všechny tři mají potenciál k odtržení člověka od přírody a těla od ducha, jejich spojením dochází k synergii a k urychlení tohoto procesu. Postupně byla příroda oddělována od městského prostředí, ale také lidská přirozenost od uměle vytvořených systémů a v důsledku toho došlo k oddělení lidského těla a mysli.

Svého prvního extrému toto rozštěpení lidské přirozenosti dosáhlo v době zavedení a rozvoje pásové tovární výroby, tj. od první čtvrtiny 20. století. Jedná se o technologii oddělující tělo od mysli, do zájmu kapitálu však primárně zapojující tělo. Stejnoměrný

\footnotetext{
Důkazem tohoto tvrzení může být zpověd’ Jonathana I., muže trpícího synestezií, tedy ztrátou barevného vidění: „Většina jídla mu připadala nechutná - např́íklad rajská jablka se mu zdála černá. Barva manželčiny kůže mu připadala krysí a nedokázal se s manželkou milovat; ani zavření očí nepomáhalo. O svou vysoce rozvinutou barevnou představivost přišel. Dokonce i jeho sny ztratily předchozí živou barevnost" [Crick 1997: 168]. Věc však není v této perspektivě pasivním předmětem, ale nabývá jistou aktivitu, kterou na pozorovatele působí, podmaňuje si jej. Věci symbolizují určité chování, které nám připomínají, což je také prríčina toho, podle Merleau-Pontyho, proč se rủzní lidé obklopují různými věcmi. O této vlastnosti věcí, o jejich schopnosti symbolizovat chování, určit události a schopnosti vyvolávat je z paměti hovoří také filosof Daniel Denett v knize Druhy myslí. Zaměřuje se především na starší lidi a na známý fakt, že se často nejsou schopni po přestěhování sžít $s$ novým prostředím a jejich fyzické i psychické chátrání končící brzkou smrtí, která by v původním prostředí, mezi věcmi obdařenými smyslem a sloužícími jako jakási externí pamět tak brzo nepřišla [Denett 1997: 129]. $\mathrm{Z}$ našeho pohledu je pak neméně důležitý př́stup Gastona Bachelarda, který vidí v jednotlivých živlech (vzduch, voda, oheň, země) ,jakousi domovinu pro určitý druh lidí, jež dává látku jejich snům, je oblíbeným prostředím imaginace, jež řídí jejich život a přirozenou svátostí, jež jim dodává sílu a štěsti' [Merleau-Ponty 2008: 32]. Věci tedy nejsou souhrnem vlastností, které teprve intelekt spojuje dohromady. Vztah člověka k věcem nelze omezit na pozorování chladného rozumu z pozice pevného bodu, ale lze jej popsat jako živý, oboustranný a zahrnující rozum, emoce, smysly i tělesnost.
} 
pohyb pásu, rutinní pohyby zaměstnanců, to je hlavní charakteristika pásové výroby, ale i činností v soukromí, které jsou často tovární logikou inspirovány. ${ }^{4}$ Práce vyžaduje pouze zvládnutí několika zautomatizovaných a zefektivněných pohybů, zapojuje tedy starší mozkové vrstvy, neokortex stojící za naší lidskostí však mohl ráno, při odchodu do zaměstnání zůstat doma na nočním stolku.

Druhý vrchol odtržení těla a mysli zažíváme v současné době. A to přes optimistické předpovědi a naděje spojované s počítačovou technikou, která měla průmysl a techniku přiblížit člověku. Naděje vyrůstaly z osvícenského a modernistického ztotožnění lidství a člověčenství s rozumem. Tyto předpovědi se však nenaplnily, došlo zato k převrácení dřívější nerovnováhy těla a mysli ve prospěch mysli. Konkrétněji ve prospěch instrumentálního rozumu. Naše životy se z valné části mění na existenci umrtveného těla a oddělené mysli řešící rozmanité instrumentální úlohy nejrůznější náročnosti. Umožněno to je stále pokračující automatizací manuální, ale i intelektuální práce. Činnost robotů i lidská práce jsou pak zapojeny do produkčních procesů, v nichž každý jednotlivec vykonává (řídí, organizuje, koordinuje) jednu omezenou část. To samé platí i pro nevýrobní sféry, kde jsou administrativní procesy také rozfázované do jednotlivých částí, které vykonávají k tomu vyškolení pracovníci. Podstatné však je omezení pohybu, soustředění pohledu do jednoho místa a ztráta jakéhokoliv osvojení prostoru.

\section{Město jako protipřírodní bariéra}

Kultury se původně vyvíjely v souladu s nadřazeným, všeobjímajícím a život poskytujícím přírodním rámcem. Jejich vývoj je však neřízený a kumulativní. Z neřízenosti kulturního vývoje vyplývá, že podobně jako v prrípadě biologické evoluce je optimální řešení hledáno většinou postupně. Určitý nově vzniklý systém je postupně vylepšován, popřípadě je od ostatních kulturních systémů odstiňován tak, aby nerušil jejich životaschopnost. Kumulativnost pak znamená, že vznik jednoho systému podmiňuje vznik systémů nových.

Př́kladem, který zde za všechny uvedu je automobilismus, nebo automobil a systémy umožňujícího jeho masový provoz. Roku 1885 spatřil světlo světa první Benzův automobil. Roku 1913 zavedl Henry Ford pásovou výrobu vozu Ford T a umožnil tak jeho masové rozšíření [Macbeth 1985]. Automobil se stal hrdinou, který prý vyřeší téměř všechny společenské problémy. První trhliny však tento optimismus dostal již ve 20. letech 20. století, kdy začala být centra amerických měst beznadějně ucpána kolonami automobilů. Od této chvíle je rozvoj měst stále určován potřebami automobilismu. Politici a technici se neustále snaží novými metodami a technickými systémy předcházet naprostému dopravnímu chaosu a neobyvatelnosti měst [Keller 1998]. Automobilu se však přizpůsobují další a další oblasti života a vznikají nové, s ním spojené kulturní struktury. Automobil vstupuje do umění, do filmu a samožrejmě do reklamy. To vše způsobuje další růst automobilismu. Ten a snaha o jeho alespoň částečné spoutání tak připomíná

Automatické a poloautomatické př́stroje ergonomicky tvarované a umístěné s myšlenkou na maximální racionalizaci pohybu, polotovary atd. V př́ípadě privátní techniky však lze namísto o fordismu hovořit o taylorismu. 
boj s dopingem ve vrcholovém sportu. Byt’ se to dnes snažíme maskovat, je automobil stále základní silou určující podobu měst. Kulturu jako samostatnou vrstvu reality popsal americký antropolog a spoluzakladatel oboru kulturologie Leslie A. White [Soukup 1996: 153-157]. Kulturní procesy postupně zatemňují, až zcela přetrhávají vazbu na přirozený svět jako nejzazší horizont. Novým horizontem se tak stává uměle vzniklá kultura, která pak je určujícím rámcem pro další kulturní rozvoj i jednání jednotlivců. Po dlouhá tisíciletí však zůstával vliv kultury a přírody v přibližné rovnováze, o skutečném odtržení lze hovořit až v moderní městské civilizaci.

Město lze v tomto kontextu vnímat jako záznam výše popsaných procesů. Po dlouhá staletí byla města vůči přírodě fyzicky uzavřena (valy, hradby, př́kopy), nebyla však zpřetrhána přímá vazba na úrodnost okolní krajiny, kvalitu a množství vody z řek či studní, nebyl potlačen přirozený běh času, střídání dne a noci, ročních období. Už vůbec nelze mluvit o tom, že by městské obyvatelstvo v těchto obdobích bylo zbaveno závislosti na fyzické práci a s tím spojeným rozvojem v genomu zakódovaných programů rozvoje lidské osobnosti. K zásadní změně došlo během průmyslové revoluce. $\mathrm{V}$ této době se na základě nově pojaté matematické vědy, určené v prvé řadě k dosahování praktických cílů a ovládání přírody, začínají rozvíjet rozsáhlé technické systémy. Nejprve vznikají izolovaně v původních či nově vznikajících centrech, posupně se však propojují železnicí, silnicemi, telegrafem, telefonem a rozmanitými energovody. Města tak přetrhávají svou závislost na okolní krajině zemědělské, ale také na blízkých zdrojích energie.

Nejdůležitějšími technickými vynálezy umožňujícími nebývalý rozvoj moderní architektury, ale také iluzi nadřazenosti a nezávislosti na př́rodě jsou výtah s pojistkou, velkorozponové konstrukce - ocelové, předpínaný beton apod., vzduchotechnika. Rozvoj a růst měst byl katalyzován rozvojem systémů jako jsou moderní vodovody, elektrický proud a jeho rozvody a především osobní dopravní systémy individuální, hromadné, přepravující velké množství lidí uvnitř měst a nákladní, umožňující zásobování měst i z velmi vzdálených lokalit, to vše nejnověji doplňované o řízení informačními technologiemi.

Vodovody zdánlivě oddělují městské obyvatelstvo od zdrojů vody, ničí tak povědomí o jejich zranitelnosti, o potřebě jejich ochrany. ${ }^{5}$ Umělé osvětlení umožňuje prodlužovat den dlouho do noci a to nejen ve firmách a v domácnostech, ale také ve veřejném prostoru. ${ }^{6}$

Elektrická energie, výtahy, moderní konstrukce, vzduchotechnika umožňují budování rozsáhlých obchodních, zábavních či multifunkčních komplexů nabízejících prostor, v němž lze strávit nejrůznějšími zábavními činnostmi celé dny. ${ }^{7}$ Dochází k přesunu čin-

\footnotetext{
V historii se současnému stavu přibližily snad pouze římské akvadukty.

6 Obzvláště negativní je, a to přes obecnou oblíbenost, nasvětlování jednotlivých památek, nebo jejich souborů v průběhu celých nocí. Negativní není pouze nadměrná spotřeba elektrické energie a tvorba světelného smogu, ale také další narušení a hlavně ochuzení přirozeného běhu věcí. Za přirozeného a přiměřeného umělého osvětlení má památka jiný charakter v letní a zimní noci, za úplňku či novu, $\mathrm{v}$ zamračeném či deštivém počasí, ve chvílích těsně po setmění či později v noci. Kromě toho ne všechny památky jsou „mrtvé“. To znamená, že žijí i jiným než muzeálním životem. Zhasnutí či rozsvícení v oknech o tomto životě vypovídá. Prudké nasvícení všechny tyto rozdíly ruší a stavbu přibližují „ideálnímu stavu“ na fotografí́ch turistických katalogů.

Technické prostředky umožňující jejich výstavbu samožrejmě nebyly jejím jediným důvodem. Další př́činy byly ekonomické - maximalizace zisků obchodníků, společenské - rozvoj konzumní společnosti, rozvoj automobilové dopravy ničící veřejné městské prostory, proces, který však byl výstavbou obchodních center dále umocněn. Existence technických prostředků umožňujících výstavbu těchto obřích center tak byla spíše katalyzátorem jejich výstavby.
} 
ností dřive spojených s venkovním prostorem do prostoru uzavřeného, hovoří se o privatizaci veřejného prostoru. Změna v jeho charakteru však nesouvisí pouze s ochranou před povětrnostními vlivy. Privátní prostor je samozřejmě jako privátní organizován, tím dochází k potlačení charakteru veřejného prostoru a ke zdůraznění funkcí a zájmů privátních. ${ }^{8}$ Ve spojení s dopravní technikou (především individuální) umožňuje, ale také vnucuje současné město životní styl, při němž nemusí docházet k žádnému kontaktu s přirozeným prostorem. Byt, pracovní místo, nákupní a zábavní centrum, automobil se mohou stát a také se stávají skutečným a jediným prostředím našich životů. Kontakt $s$ vnějším prostředím a informace o něm je omezena na rtutový sloupec teploměru. Propojení s př́rodním světem jako zdrojem energie a surovin nutných pro vedení tohoto životního způsobu je zprostředkováno abstraktními systémy [Giddens 1998]. Ty zároveň slouží jako dokonalá bariéra uvědomění si dopadů vlastního jednání a tudíž i brzda jeho změny. Odtud tvrzení mnoha environmentálních myslitelů, že současná civilizace nutí k ekologicky nešetrnému jednání i ty jedince, kteří se o změnu chtějí pokusit.

Na základě dopravních a informačních technologií dochází ke vzniku celosvětové městské sítě. Ta však není jednovrstvá, ale je hierarchicky uspořádaná, a to od světových center na vrcholu, přes centra regionální a národní, až k městům lokálního významu. Města jsou však unifikována stejnými ekonomickými a organizačními principy. Společná celé síti je její závislost na vnější krajině, která se tak, vzhledem k rostoucí velikosti měst i nárokům jejich obyvatel, stále více stává jejich zásobárnou surovin a energie a rekreačním prostorem jejich obyvatel. Zatímco zemědělství a zásobování měst jeho produkty nebylo $\mathrm{v}$ prrímém rozporu se zájmy vesnického obyvatelstva, je tomu v případě krajiny coby zdroje surovin a energie pro rozrůstající se městskou sít jinak. V nejhorších případech dochází k exploataci celých krajin a ničení vesnic a vystěhovávání obyvatelstva. V méně dramatických př́padech dochází k zástavbě krajiny stavbami z nichž nemá místní obyvatelstvo přímý užitek. Nejaktuálnějším příkladem je výstavba slunečních elektráren, ještě výrazněji pak mohou krajinu ovlivnit větrné elektrárny. Takovéto stavby mohou totiž degradovat krajinu, která by se bez jejich př́tomnosti mohla stát vyhledávaným turistickým cílem a obživou pro venkovské obyvatelstvo, které již dávno není primárně živeno zemědělstvím.

Tak jako v kultuře dochází i ve městě k neustálému překrývání a doplňování starších vrstev novými tak aby byla zajištěna jejich alespoň částečná kompatibilita s dalšími subsystémy. Jako př́klad v článku uvedu dnes velmi častá opatření proti dopravnímu hluku. Nejviditelnějšími jsou protihlukové bariéry. Ty sice ochrání přilehlé prostory před hlukem, důsledkem je však zcela nepřirozené členění městského prostoru, ztěžující, tak jak to činí řada jiných technických systémů, pohyb pěších. S automobilovou dopravou dále souvisí její př̀kládání na vnější okruhy, opět vedeno pouze antropocentrickým cílem ochrany obyvatel, bez ohledu na újmy krajiny a přírody, které toto řešení přináší. Kromě samotného záboru půdy především dále rozšiřuje hranice města, kouskuje krajinu a ztě-

8 Příkladem je v současnosti dokončená přestavba Hlavního nádraží v Praze. Umístění pokladen je záměrně voleno tak, aby cestující musel projít mezi všemi nově zř́zenými obchody. Toto řešení je známé z letišt. Pro správnou funkci obchodních center se užívá řada dalších opatření, která mají podpořit nákupy a vypudit ty, kteří zde nakupovat nechtějí. Řešení legitimní, pouze však v př́padě, že nebude docházet k pojmovému zamlžování a označování těchto prostor za plnohodnotnou náhradu skomírajícího prostoru veřejného. 
žuje v ní pohyb lidem, zvěři, ale i migraci vegetace. Jiným př́kladem adaptace na starší a silnější systémy jsou protihluková okna instalovaná v domech poblíž letišt. Ta mají zaručit nezměněnou kvalitu života, ovšem pouze za předpokladu, že přirozeným životem je život uvnitř. Obdobná řešení se užívají také podél frekventovaných ulic, v př́ípadě Prahy např̀. u severojižní magistrály.

Zmíněný kulturní mechanismus, však přináší v reakci na současný stav městského potažmo kulturního organismu i skutečně přínosné struktury, prvky a zvyky. Uvedu alespoň šírící se městské farmy, pěstování zeleniny na balkonech, zavádění zelených fasád a střech, vznikající jako reakce na protipřírodní vyprahlé městské prostředí. ${ }^{9}$ Jako zdařilý příklad představím pouze pařížský obytný dům od Edouarda Francoise, jehož balkony jsou obehnány zábradlím tvořeným obřími květináči s bambusem [Suske 2008: 110]. Zcela jiným prrístupem $\mathrm{k}$ přenesení přírodních forem do měst je jejich nápodoba architekturou. Touto cestou se vydává tzv. organická architektura ${ }^{10}$ využívající k navrhování např. teorii fraktálů, jejichž charakter mají v živé př́írodě např. stromy, v neživé př́rodě pohoří. Jiným př́istupem je tzv. parametrická architektura, umožňující simulovat složité přírodní struktury. Pravděpodobně první parametricky navrhovanou realizací v ČR je Cafébar ve Starém Městě u Uherského Hradiště od Michala Kutálka. Ve světě pak např. CET v Budapešti od trojice Marthijn Pool, Kas Oosterhuis a Ilona Lénárd, či projekt administrativního centra Zilverparkkade od René van Zuuk Architekten. Záměrně nepíši o „zelené architektuře“, nebot ta svou podobou nemusí do městského organismu přinášet vizuální prvky odkazující k původnímu přírodnímu prostředí. ${ }^{11}$

Výše zmíněné příklady snad přibližují poněkud abstraktní odlišení symbolu a znaku a jejich promítnutí do hmotné reality. Prostředí, které mezi nimi udržuje rovnováhu, prostředí, v němž nedošlo k potlačení původního smyslu symbolů a jejich záměně za znaky, je většinou prostředím, ke kterému se chce člověk vracet. Prostředím, které si uchovává tajemství, které nás láká a které chceme odhalit. Jedná se o prostředí, které odráží labyrint naší mysli a se kterým tak můžeme souznít.

Nicméně stále rostoucí urbánní svět v populaci prohlubuje potřebu krajiny a prrírody ${ }^{12}$ jako prostředí, v němž člověk jako živočišný druh vznikl, a na které je psychicky i fyzicky stále adaptován. Vztah ke krajině však nabývá nových kulturně formovaných podob. Pod tlakem současného ekonomického a kulturního modelu se však místa určená k naplně-

9 Tvrzení komplikují novější přírodovědecké výzkumy (např. D. Storch, Z. Veselovský), podle nichž města poskytují útočiště celé řadě živočišných a rostlinných druhů. Je tedy snad lépe hovořit o reakci na náš životní způsob, který tuto skutečnost nedovoluje zaznamenat. Skutečností však také je, že pro lidský prožitek př́rody je důležitý krajinný ráz a ne pouze izolovaně žijící druhy.

10 Pojem organická architektura je však velice nejednoznačný a rozhodně neoznačuje ucelený architektonický směr či myšlení. Poprvé se objevil pravděpodobně již v roce $1841 \mathrm{v}$ knize $\mathrm{O}$ umění a kráse od H. F. R. de Lammenaise, užívali jej též J. G. Semper a L. H. Sullivan, často je spojován s dílem F. L. Wrighta.

11 Pouze okrajově zde chci zmínit obecnější problém ekologických řešení, která přes svůj šetrný vztah $\mathrm{k}$ př́rodě nemusí být v souladu s evolučně vytvořenými schématy přirozeného světa. Casto jsou tato řešení realizována na mikroskopické úrovni, bez přímého vizuálního vztahu k lidskému „mezosvětu“, nebo jsou v něm př́istupná, ale opomíjejí estetickou či psychologickou stránku reality. Taková řešení musí být prosazována pouze na racionální úrovni, což může být problematické a navíc nepřispívají k lepší obyvatelnosti prostředí.

12 Ta se začala objevovat již v 19. století a stála u zrodu moderní turistiky, letních bytů, chat a trampingu. V současnosti však nabývá masovějšího charakteru a je vázána na řadu tzv. outdoorových aktivit. 
ní této potřeby vřazují do národních i nadnárodních urbánních sítí. Pomineme-li stále okrajovou měkkou turistiku, dochází pod turistickým a rekreačním tlakem k urbanizaci a technologizaci krajiny. Krajina se často stává pouhou estetickou kulisou jiným, prostorově i energeticky náročným činnostem. Jejich bujení v místech, která kontakt s přírodou nabízí je známkou stále se šírící Nudy a manipulace člověka tržními mechanismy současné civilizace [Patočka 1990]. Nutnost cestovat za krajinou a př́rodou do k tomu uzpůsobených míst je dána devastací některých částí příměstské ${ }^{13}$, ale i od měst vzdálenější krajiny coby zázemí městské sítě tak jak o tom píšu výše. Jak uvádí Hana Librová, ještě v první polovině 20. století stačila tato krajina k plnému mimoměstskému vyžití městských obyvatel [Librová 1987]. Lidé vedení skutečnou biofilní touhou po krajině tak jdou stále dál, hloub do př́rody, v patách jim však jdou vyslanci urbanizovaného turistického zábavního průmyslu. Zajímavě přistupuje k měnícímu se využití krajiny Miloslav Lapka, který zavádí pojem PETosféra. Ten zachycuje nástup nové éry na venkově, jejímž těžištěm je př́roda, estetika a turistika [Lapka 2008].

\section{3. Člověk ve spárech informačních technologií}

Již víme, že se člověk pohybuje ve dvou vztažných prostorových soustavách. Jedna je dána základními vlastnostmi a charakterem vnějšího prostředí, druhá se odvozuje od člověka, který je jejím pomyslným středem. Při vlastní genezi se člověk sice vymezuje vưči vnějšímu světu, nikdy však nezpřetrhá pouta, která ho s ním vážou. Naopak vnější podmínky jsou důležitým činitelem při zdravém utváření lidské osobnosti. Tělo a mysl jsou neoddělitelné, mysl je formována naším vztahem ke světu, k prostoru. Moderní informační technologie rychle se širrící v současném urbanizovaném světě však tento vztah narušují. Fyzické obeznamování s prostředím je stále více nahrazováno audiovizuálním poprrípadě pouze vizuálním vnímáním. Manipulace s předměty se stále více omezuje na jejich ovládání prostřednictvím ovládacích prvků. Děti vyrůstající v tomto prostředí jsou ochuzeny o řadu pohybových aktivit, nejenom ve volné přírodě, které přispívají k rozvoji jemné motoriky a optimální genezi jejich osobnosti. Pouze vizuální informace z monitoru počítače nemůže nahradit skutečný fyzický kontakt s předměty, rostlinami a s živými tvory. Informační technologie v této perspektivě vystupují jako druhá bariéra, vedle té tvořené staršími technickými systémy, která člověka neodděluje pouze od přírodního prostředí, ale odděluje jej i od světa vlastní hmotné kultury, od světa artefaktů. Svět digitálních přístrojů omezuje smyslové seznamování s materiály umožňující niterné propojování jejich kvalit, omezuje prozkoumávání mechanismů, rychlé střídání obrazů znemožňuje jejich skutečné prožití.

Distance od vlastního kulturního prostředí se projevuje v neschopnosti vnímat jeho různé kvality. $\mathrm{V}$ urbanistickém měřítku se to odráží v prostorovém chaosu před-

${ }_{13}$ Př́íkladem jsou suburbanizované oblasti velkých českých (Praha-Jesenice, Zeleneč, Brno-jih) i evropských metropolí, ale také dopravní systémy fragmentující příměstskou krajinu. Podle Zprávy o stavu přírody a krajiny vydávané Ceskou agenturou životního prostř̌edí CENIA činil průměrný roční úbytek zemědělské půdy v letech 2000-2008 3902 ha, což představuje asi 10,7 ha denně. V letech 2007 a 2008 přesáhl roční úbytek zemědělského půdního fondu 5000 ha. Během let 1980-2005 klesl podíl nefragmentované krajiny v ČR z $81 \%$ na $64 \%$ rozlohy státu, přičemž do roku 2040 se má dále snížit na $53 \%$ [Miko, Hošek 2009]. 
městských a příměstských zón, proti kterému v současnosti protestují architekti a jiní profesionálové, ale širší veřejnost jakoby byla s tímto stavem smířena. Na úrovni architektonické se pak vzniklá distance projevuje v použitých materiálech, které často neposkytují haptickou, ale často ani vizuální pohodu, nemluvě o pohodě akustické. ${ }^{14}$ Právě tyto vlastnosti tradičních materiálů ale stojí, kromě jiného, za přitažlivostí historické architektury. Další vlastností moderních syntetických materiálů je jejich jakási vytrženost ze světa. Jak dokazuje Christian Norberg-Schulz, tradiční prŕírodní materiály odkazují k místu svého původu, mohou spojovat sídlo s okolní krajinou, díky představě o způsobu jejich vzniku, mohou odkazovat na lidskou práci za nimi stojící [Norberg-Schulz 1994].

Virtuální svět se dnes stává nutným východiskem i pro ty, kteří se mají o kvalitní prostředí sídel starat, tedy pro architekty. Výkresy provádějí v počítačových programech, s místem stavby se často seznamují prostřednictvím internetových obrazových map, materiály vybírají z mnohasetstránkových katalogů. A to vše již od dob studií. Jak tento přístup kontrastuje s praxí velkých architektů minulosti či žijících př́íslušníků starších generací. Připomeňme jen, že Josef Zídek se v době svých studií architektury nechal, aby ovládl řemeslo a poznal materiál, zaměstnávat jako zednický učedník [Ksandr 2009]. Le Corbusier byl vyučeným rytcem, Ludwig Mies van der Rohe byl synem kameníka a od svých 15 let pracoval jako stavební dělník a nositel Pritzkerovy ceny za rok 2009 Peter Zumthor se vyučil truhlářem. Není asi náhodou, že z mužů, kteří si osvojili praktickou práci s materiálem, vyrostli špičkoví architekti. A je otázkou, zda všeobecný úpadek a nezájem o tradiční řemeslo není dán, kromě struktury ekonomiky a s ní spjaté ideologie vzdělanostní společnosti, také vznikající distancí mezi člověkem a materiálním světem.

Ruku v ruce s rozvojem informačních technologií jde bouřlivý rozvoj soukromé i firemní komunikace. Komunikace představuje jednu ze základních lidských schopností, tento fakt pak vyvolává optimismus, že technika v informačních technologiích získala konečně svou lidskou tvár. Práce i soukromý styk s lidmi se postupně a zdánlivě přirozeně mění na „nekončící hovor“. Domlouváme, koordinujeme, propagujeme, hovoříme o svých zážitcích, o svých pocitech, zdánlivě lidská idyla. Je tomu tak skutečně? Řeč se podle Josefa Šmajse zrodila jako instrument, jako nástroj sloužící rozvoji a integraci kultury [Šmajs 2011]. Podle Jana Patočky má však řeč v sobě vždy něco osobního, vždy vyjadřujeme náš vztah k věcem a ke světu, funkcí řeči je ale také osobní úleva, slouží jako jakýsi citový či emoční ventil [Patočka 1992: 131]. Lze snad tedy říci, že řeč je kulturně konstitutivní, člověk v ní však vyjadřuje vždy to, oč mu v kultuře bytostně jde. Kultury se vyvíjely jako malé celky k nimž byl člověk vázán, a o které mu skutečně šlo. Současná městská civilizace však ve svých strukturách často výše zmíněné aspekty řeči odděluje. $\mathrm{Na}$ jedné straně je člověk nucen stále častěji komunikačně zprostředkovávat věci, s kterými není skutečně bytostně vázán, na druhé straně v osobní (a často právě internetové komunikaci) jsme svědky nesmyslného seberozebírání, infantilního citového vylévání či sdělování zcela banálních informací.

Oba řečové extrémy však něco postrádají, a to originalitu vyvěrající ze skutečné racionality, tedy ze svazku emocí, citu a rozumu. V obou prrípadech je ke komunikaci užíváno určitých předem daných forem a komunikačních schémat. Byt’ v každém z obou případů

14 Stále častěji se prosazují materiály bez textury, ploché, neumožňující jemnou hru stínu, s malou tepelnou kapacitou, nenavozující tedy tepelnou pohodu (jak je př́iemný chladný kámen v horkém létě). 
konstruovaných pro dosažení jiných účinků. Lze snad tedy rozšírit tvrzení Konrada Paula Liessmanna o industrializaci vědění postřehem, že byla industrializována a technologizována také řeč [Liessmann 2008: 30]. Ta však slouží pouze mechanické obnově stávající městské civilizace. Dále izoluje člověka od přirozeného světa, na který byla alespoň podle E. Cassirera původně vázána. Město je prý stav mysli, působením všech druhů techniky se však stává stavem totálním, stavem bez alternativ.

\section{Závěrem}

Na předchozích stránkách jsem se pokusil ukázat, že město je zhuštěným konglomerátem všech čtyř složek kultury, tak jak jsem je určil v první části tohoto textu. Byt v jednotlivých obdobích rozhodují o vývoji a rozvoji měst městští představitelé, neurčují směr a podstatu jejich celkového směřování. To je dáno charakterem dobové kultury, která je dynamickým systémem jejích výše uvedených složek a tvưrčí činnosti člověka. Z dlouhodobého pohledu vzniká město i kultura spontánně, a lze hovořit o samopohybu ve smyslu v jakém tento pojem užívá Václav Havel [Havel 1999]. Tento vývoj se urychlil se zrodem moderní vědy, techniky a byrokracie, které jsou nutnými podmínkami fungování moderního města. Od dob průmyslové revoluce městský organismus vstřebává stále nové systémy, které př̀es dílčí snahy o usměrňování a řízení vedou město podle jim imanentní logiky.

Nástup informačních technologií svou razancí a silou umocněnou kombinací volného obchodu a vládní podporou snad ještě překonává výše popsaný rozvoj automobilismu. Opět žijeme v době, která věří, že rozvoj určitého druhu techniky pomůže vyřešit společenské, ekologické a jiné problémy. Ale také žijeme v době, která je nucena řešit první problémy s touto technikou spojené. A opět žijeme v době, která odmítá vidět, že jsou tyto problémy této technice imanentní. Již Martin Heiddeger přesvědčivě ukázal, že technika není neutrální. Technika není dobrá, když je dobře použita a zlá, když je užita špatně. Technika se stává nebo se již stala tím, co určuje charakter lidského světa, vtiskává mu však svou ne-lidskou podstatu. Podstatou technikou daného prrístupu ke světu je jeho zvěcňování. Technika klasického průmyslového věku činila z veškerého přírodního jsoucna zdroj pro své vlastní fungování, pro obnovu svého fyzického těla, pro produkci, která obhajovala její existenci. Současná technika však obdobným zpo̊sobem uchopuje lidskou mysl, řeč i veškerou komunikaci. Informační technika svými obrazovými výstupy vytváří kulisu, která se stává naším každodenním světem. A zároveň svou sítovou, procesní podstatou spoutává veškerý lidský svět do jednoho systému s nesmírným tlakem na standardizaci a unifikaci a s umocněním procesů spojených s první vlnou technologizace světa.

Města ve svém organismu odrážejí vývoj techniky i duchovní kultury (umění, filosofie) s ní spjaté. Od izolovaných ostrovů v kulturní a přírodní krajině se postupně proměnila za přispění moderní techniky v sít, která zahrnuje stále větší množství sídel. Součástí tohoto stupně urbanizace je postupná přeměna volné krajiny v hospodářské a rekreační zázemí rostoucích měst. Technika spolu s nastavením současného ekonomického systému přispívá k jisté introverzi urbanizované společnosti. Postmoderní městská kultura žije ve falešné iluzi soběstačnosti dané odtržením nejenom od původního přírodního světa, ale i od hlubších vrstev lidské psychiky, od starších struktur lidského mozku. 
Přes bouřlivý a pestrobarevný růst městské kultury však hrozí hluboká krize její i prrírodního prostředí, které je její podmínkou a základem. Jak jsem napsal výše, aby byla kultura životaschopná, musí se ve vzájemném souladu vyvíjet všechny její složky symbolický systém, znakový systém, jednání a jeho regulativy i artefakty. Symbolický systém je však v současnosti upozaděn, do popředí se $\mathrm{v}$ rámci duchovní kultury dere systém znakový, tedy systém řídící a organizační, systém, který je vlastní podstatou informačních technologií. Kultura však svou vitalitu čerpá ze symbolického systému, který byl vždy těsně svázán s nevědomou složkou lidské psychiky a s kulturu obklopující př́rodou. Symboly otvírají cestu k celku světa, z něhož vyvěrají kulturní hodnoty určující jednání jednotlivce a v podobě sociálních norem ovládají společnost. Přičemž normy jsou racionalizovaným a dobově podmíněným vyjádřením hodnot. V současné společnosti se však normy přestávají odvozovat od hodnot, ale jsou zcela racionálně vykonstruované [Mucha 2000]. Jejich posláním je řízení, udržení a integrace technických a společenských systémů, odtržených od př́rodního světa. Naše městská civilizace se mění nebo již proměnila $v$ gigantickou továrnu, $v$ dnešní terminologii spíše firmu, tak jak to podle Erazima Koháka ve svém díle předpovídali Karel Marx a Bedřich Engels [Kohák 2010: 306]. Naše městská civilizace dosáhla již stavu předvídaného M. Heiddegerem v němž se stala svět odkrývající silou pro většinu obstarávající populace technika. Civilizace, v níž více než 50 \% populace žije ve městech se bez sofistikované techniky nemůže obejít. Co však lze, a co je úkolem především humanitních myslitelů, je neustálé odkrývání a zjevování skutečné tváře techniky. Ukazovat, že svět tak jak jej odhaluje technika, není jediný možný, že se nejedná o nejzazší hranici lidského světa, že technika nezjevuje skutečnou bytnost lidského světa a že nemusí být tím jediným, co určuje povahu naší městské civilizace.

Je nutné nově promýšlet a interpretovat hodnoty vyvěrající z hlubin přirozeného světa a následně podřídit znakový systém systému symbolickému, tedy podřídit sociální, technický a ekonomický systém hodnotám. S jistou dávkou zjednodušení lze tvrdit, že kultury jsou vázány lokálně, zatímco civilizace zahrnují větší geokulturní celky. Příkladem, kdy byly kultury sjednoceny nadřazenou civilizací je kupř́ikladu doba helénismu, která vedle geniálních kulturních a filosofických děl přinesla také pocit odcizení či ztracenosti obyvatel. Lze vyvodit, že kultura je začleňující, s rizikem zotročení před nímž varuje např. N. Berdajev, zatímco civilizace odcizující, odcizení pojímám ve smyslu J. J. Rousseau jako vzdálení se vlastní, lidské přirozenosti a současně podřízení se vnějším systémům, sociálním i technickým. Překonáním negativ kultury a civilizace je jejich vyvážený vztah. V ekonomice se, zjednodušeně řečeno, jedná o napojení lokálních ekonomik na ekonomiku národní i nadnárodní, ovšem při zajištění dostatečně dlouhodobého udržení peněz v místě. Takováto ekonomika je silně vázána na fungující komunitu. Úkolem architektury je podpora nejen těchto komunit, ale i maximalizace oběhů peněžních jednotek v místě. Jedná se tedy na jedné straně o vytváření životního prostředí, v němž mohou fungovat malé podniky soukromého, družstevního, obecního či komunitního charakteru a zároveň užívání místních materiálů i místní pracovní síly. ${ }^{15}$ Rovnováha mezi místními

15 Vše psáno s vědomím, že architekti a architektura nejsou tvưrci nových světů, jak o tom snila meziválečná avantgarda. Svou prací však mohou napomoci k urychlení některých žádoucích společenských a kulturních změn. 
a neregionálními procesy přináší větší svobodu v rozhodování o využití území. ${ }^{16}$ Přináší opětovné vědomí hodnoty zemědělské půdy, které pak tlačí na intenzívní, zahuštěnou výstavbu. Možnou cestou je preference obecní zahuštěné zástavby, ze které je však všem rychle přístupná volná krajina v okolí sídla, před do volné krajiny se rozpínající privátní zástavbou, poskytující každému kousek soukromé zeleně či výhled na nehlubokou parkovou vegetaci. Je třeba neustále připomínat a rozpracovávat názor L. Žáka, že i volné místo je architektura, a že volná krajina je cennější než zástavba. Možné je také navázat na vize labyrintických městských prostorů rozpracovávané v šedesátých letech. (např. Smithsonovi, van Eyck, Jacob Bakema, atd.) A právě zde je, domnívám se, velký prostor pro rozvíjející se parametrické způsoby navrhování. Cestou, která může spoluutvářet symbolickou vrstvu sídel, vrstvu, která již nemůže být spjata s jedním náboženstvím, či jiným velkým vyprávěním, je uliční umění a nově se rozvíjející urbánní akupunktura. Je tak možné usměrňovat energii města a vytvářet prostorové body, jimž mohou rozmanité sociální skupiny a subkultury připisovat symbolické významy. Snad tato cesta může zmírnit dopady městské civilizace na přirozený svět, snad může alespoň jeho části vyrvat ze spárů její strojové racionality. ${ }^{17} \mathrm{~V}$ současné době se však zdá, že zatím lidstvo není ochotno opustit dosavadní cestu a je rozhodnuto skřítky a víly ze svého pravoúhlého a plochého světa vyhnat.

\section{LITERATURA}

Cassirer, Ernst. 1996. Filosofie symbolických forem I. Praha: OIKOYMENH.

Crick, Francis. 1997. Věda hledá duši. Praha: Mladá fronta.

Denett, Daniel. 1997. Druhy myslí. Bratislava: Archa.

Giddens, Anthony. 1998. Di̊sledky modernity. Praha: Sociologické nakladatelství.

Havel, Václav. 1999. Moc bezmocných. Praha: Torst.

Keller, Jan. 1998. Naše cesta do prvohor. O povaze automobilové kultury. Praha: Sociologické nakladatelství. Kohák, Erazim. 2010. Domov a dálava. Kulturní totožnost a obecné lidství v českém myšlení. Praha: FILOSOFIA.

Ksandr, Karel. 2009. Josef Zítek architekt, pedagog a památkář. Praha. Národní divadlo.

Lapka, Miroslav. 2008. „Krajina jako PETosféra.“ Vesmír 87 (1): 36-36.

Librová, Hana. 1987. Sociální potřeba a hodnota krajiny. Brno: Univerzita J. E. Purkyně v Brně.

Liessmann, Konrad Paul. 2008. Teorie nevzdělanosti. Omyly společnosti vědění. Praha: Academia.

Macbeth, Graham. 1985. Velký obrazový atlas automobilu. Praha: ARTIA.

Merleau-Ponty, Maurice. 2008. Svět vnímání. Praha: OIKOYMENH.

Mezřický, Václav (ed.). 2011. Perspektivy globalizace. Praha: Portál.

Miko, Ladislav, Michael Hošek (eds.). 2009. Př́roda a krajina České republiky. Zpráva o stavu 2009. Praha: Agentura ochrany př́rody a krajiny ČR. [online] [cit. 6. 9. 2011] Dostupný z: http://www.mzp.cz /C1257458002F0DC7/cz/priroda_krajina_2009/\$FILE/OZCHP-Zprava_o_stavu_prirody_a_krajiny _CR-20091130.pdf.

16 Omezení vlivu nadnárodních společností, či pouze vzdálených investorů.

17 Člověk zásadním způsobem mění životní prostředí již od vzniku zemědělství. Je proto nutné vzájemný vztah člověka a prírody studovat a určovat typ a rychlost změn, kterým chceme naše životní prostředí podrobit. Pouze pasivní ochrana a představy o naprosté minimalizaci vlivu člověka na prrírodu jsou vzhledem $\mathrm{k}$ cestě, kterou nastoupil již před tisíciletími pouhým sněním. Stejně jako opačná představa o naprosté tvárnosti člověka pro život $\mathrm{v}$ jakémkoliv prostředí a schopnosti př́rody vstř̌ebat veškeré lidské zásahy. 
Mucha, Ivan. 2000. Symboly v jednání. Praha: Karolinum.

Norberg-Schulz, Christian. 1994. Genius loci. K fenomenologii architektury. Praha: Odeon.

Patočka, Jan. 1990. Kacírské eseje o filosofii dějin. Praha: Academia.

Patočka, Jan. 1992. Přirozený svět jako filozofický problém. Praha: Československý spisovatel.

Ruddiman, William F. 2011. Pluhy, nemoci a ropa. Praha: Academia.

Soukup, Václav. 1996. Dějiny sociální a kulturní antropologie. Praha: Karolinum.

Suske, Petr. 2008. Ekologická architektura ve stínu moderny. Praha: ERA.

Šmajs, Josef. 2011. Ohrožená kultura. Brno: Host.

Tieck, Ludwig. 1974. Život básníka. Praha: Odeon.

\section{SUMMARY}

At present, more than $50 \%$ of the world population lives in towns. As a result, the town has become the predominating type of the human environment. This change raises many urban, architectonic, demographic, traffic, energetic as well as cultural-symbolic questions - the questions connected with the relationship of the man and the world as a whole. The man is an indivisible unity of body and consciousness; the contents of the consciousness are thus given also by the bodily experience of the physical world.

In the first part of the text, the author deals with the ways of the human relation to this world (space), origination of the basic spatial schemes and orientation in the space.

The author presents a thesis that the nature is an account of the depths of the being and that the relationship between the cosmos and the human spirit, the relationship, which serves as a matrix for mythology, arts, philosophy and science, has been seen from the morning of the human existence. In this article, the author examines how the spatial awareness is related to the character of the artistic, religious and rational grasp of the intuitively perceived order of the cosmos.

In the next part, the author studies the urban environment as an organism created by gradual snowballing and development of its structures. The author studies their development from the moment when towns represented the human environment for an insignificant part of the population only and when the people maintained a close link to the natural/rural environment, up to the present. Now it is typical that the town is the human environment for more than half of the world population, and the society has been thus physically and culturally separated from the natural world. As a consequence, the relationship with the natural world has been being replaced by the relationship with other cultural layers. This situation raises questions whether such closed culture may perform its typical functions, whether a system of values can be restored, or whether it is a formal, auto-reference system incapable of giving answers to the basic questions of the human existence. The author shows that the artificial technical environment serves as a background for solving both living and existential issues in many works of the mental civilisation. However, he shows that in order to solve them, it is necessary to overcome the technology as a world-governing phenomenon and subordinate it again to the sphere of values as a source of private and social standards of action. 